\title{
PENGARUH PENAMBAHAN GULA DAN SARI BUAH TERHADAP KUALITAS MINUMAN SERBUK DAGING BUAH PALA
}

\author{
ADDITIONEFFECT OF SUGAR AND FRUIT EXTRACTTO THE QUALITY OF NUTMEG \\ MEAT JUICE
}

Fetty Indriaty dan Yunita F. Assah

Balai Riset dan Standardisasi Industri Manado

Jalan Diponegoro No. 21-23 Manado

email:indriatyfetty@yahoo.com

Diterima tgl 04-05-2015, Disetujui tgl 12-05-2015

\begin{abstract}
ABSTRAK
Daging buah pala (Myristica fragrans Houtt) merupakan bagian dari buah pala yang beratnya sekitar $70 \%$ dari berat utuh, dan telah dimanfaatkan menjadi berbagai macam produk makanan. Tujuan penelitian ini ialah memanfaatkan daging buah pala untuk pembuatan serbuk instan dan mendapatkan formulasi minuman serbuk instan daging buah pala. Penelitian menggunakan metode percobaan dalam Rancangan Acak Lengkap (RAL), dengan perlakuan penambahan gula $90 \%$, sari buah pala $10 \%$; gula $80 \%$ : sari buah pala $20 \%$; gula $70 \%$, sari buah $30 \%$; gula $60 \%$; sari buah pala $40 \%$; dan gula $50 \%$ : sari buah $50 \%$. Pengamatan dilakukan menggunakan beberapa parameter pada SNI 01-4320-2004 yaitu kadar gula, kadar air, uji mikrobiologi berupa angka lempeng total dan coliform; uji pH, uji kelarutan, serta uji organoleptik terhadap rasa, aroma, dan penampakan. Hasil penelitian menunjukkan bahwa perlakuan variasi perbandingan penambahan gula dan sari buah memiliki pengaruh yang nyata terhadap kadar $\mathrm{pH}$, kelarutan, dan parameter organoleptik yang meliputi rasa, aroma, dan penampakan, serta tidak memiliki pengaruh nyata terhadap kadar air. Serbuk instan daging buah pala memenuhi syarat mutu SNI 01-4320-2004 untuk parameter kadar air dan parameter mikrobiologi yang meliputi angka lempeng total dan coliform. Perlakuan terbaik didapat pada variasi penambahan gula 60\%:sari buah $40 \%$ yang menghasilkan serbuk minuman instan dengan kadar gula $84,79 \%$, kadar air 0,4\%, kadar abu 0,53\%, dan kadar kelarutan 99,89\%, dengan uji organoleptik terhadap rasa, aroma, dan penampakan cenderung lebih disukai panelis dengan skor penilaian agak suka.
\end{abstract}

Kata kunci: daging buah pala, serbuk instan daging buah pala

\begin{abstract}
Meat of nutmeg (Myristica fragrans Houtt) is part of a nutmeg which weighs around $70 \%$ of the weight of the whole, and has been utilized in a wide variety of food products. The purpose of this research is to utilize the meat nutmeg powder for making of instant powder and formulation of instant powder. Research was undertaken using experimental methods in a completely randomized design (CRD), treatment applied were addition of $90 \%$ of sugar and $10 \%$ of nutmegfruit juice; $80 \%$ of sugar and $20 \%$ of nutmeg fruit juice; $70 \%$ of sugar and $30 \%$ of nutmeg fruit juice; $60 \%$ of sugar and $40 \%$ of nutmeg fruit juice; and $50 \%$ of sugar and $50 \%$ of nutmeg fruit juice. Observations were made using several parameters in SNI 01-4320-2004 namely sugar content, moisture content, microbiological tests such as total plate count and coliform; $\mathrm{pH}$ test, solubility test and organoleptic test for flavor, aroma, and appearance. The results showed that treatment variation of added sugars and juice has a significant effect on $\mathrm{pH}$, solubility, and organoleptic parameters which include taste, smell, and appearance, and did not have a significant effect on water content. Nutmeg instant powder met SNI 01-4320-2004 for water content parameters and microbiological parameters which include total plate count and coliform. The best treatment was obtained on the variation of the addition of $60 \%$ of sugarand $40 \%$ of nutmeg fruit juice that produces instant powder with sugar content of $84.79 \%, 0.4 \%$ of moisture content, $0.53 \%$ of ash content, and $99.89 \%$ of solubility levels. Organoleptic test for flavor, aroma, and appearance tend to be preferred by the panelists which score rather like.
\end{abstract}

Keywords: meat nutmeg, instant powder of meat nutmeg 


\section{PENDAHULUAN}

Tanaman pala (Myristica fragrans Houtt) adalah tanaman asli Indonesia merupakan salah satu komoditas ekspor yang penting karena Indonesia merupakan negara pengekspor biji dan fuli pala terbesar yaitu pemasok sekitar $60 \%$ kebutuhan pala dunia.Selain sebagai komoditas ekspor, kebutuhan dalam negeri juga cukup tinggi. Pala dikenal sebagai tanaman rempah yang memiliki nilai ekonomis dan multi guna karena setiap bagian tanaman dapat dimanfaatkan dalam berbagai industri. Biji, fuli, dan minyak pala merupakan komoditas ekspor dan digunakan dalam industri makanan dan minuman.Minyak yang berasal dari biji, fuli dan daun banyak digunakan untuk industri obat-obatan, parfume, dan kosmetik. Buah pala terdiri atas daging buah $(77,8 \%)$, fuli $(4 \%)$, tempurung $(5,1 \%)$, dan biji $(13,1 \%)^{1}$.

Daging buah pala setelah diambil biji dan fulinya, belum dimanfaatkan secara maksimal dan menjadi limbah buangan.Daging buah pala dapat dimanfaatkan untuk diolah menjadi manisan basah dan kering, asinan, dodol, selai, anggur, sari buah, dan jelly.Salah satu usaha pemanfaatan daging buah pala yaitu dengan mengolahnya menjadi minuman serbuk instan.Minuman serbuk instan merupakan produk dalam bentuk konsentrat atau terpekatkan dengan penghilangan air sehingga mudah ditambah air (dingin/panas), mudah larut dan siap dikonsumsi.

Daging buah, berwarna putihkekuningkuningan, berisi cairan bergetah yang encer, rasanya sepet danmempunyai sifat astringensia.Oleh karena itu jika buah masih mentah,daging buah pala tidak bisa dikonsumsi langsung tetapi dapat diolahmenjadi berbagai produk pangan.Setiap $100 \mathrm{~g}$ daging buah pala mengandung air sekitar $10 \mathrm{~g}$,protein $7 \mathrm{~g}$, lemak $33 \mathrm{~g}$, minyak yang menguap (minyak atsiri) dengankomponen utama monoterpen hidrokarbon (61-88\% seperti alpha pinene, beta pinene, sabinene), asam monoterpenes (5-15\%), aromatik eter (2\%-18\% seperti myristicin, elemicin, safrole). Minyak atsiri dalam daging buah pala mengandung komponen myristicindan monoterpen. Komponen myristicin dalam daging buah pala dapatmenimbulkan rasa kantuk ${ }^{2}$.

Sukrosaadalah disakarida non reduksi yang mengandung delapan grup alkohol, tigadiantaranya adalah gugus hidroksil primer dan yang lainnya adalah gugus sekunder ${ }^{3}$. Sukrosa adalah oligosakarida yangmempunyai peranan penting dalam pengolahan makanan dan banyak terdapat padatebu, bit, siwalan dan kelapa kopyor ${ }^{4}$.

Kemanisan Odari sukrosa sama dengan 1.00 dan biasanya industri makanan menggunakan sukrosadalam bentuk kristal halus atau kasar dan dalam bentuk cairan sukrosa ${ }^{5}$.

Gula merupakan salah satu bahan pemanis yang penting karena hampir setiap produk menggunakan gula. Gula kristal berwarna putih digunakan sebagai bahan pembuatan sirup atau sebagai bahan campuran dalam adonan ${ }^{6}$.

Produk pangan instan didefinisikan sebagai produk dalam bentuk konsentrat atau terpekatkan dengan penghilangan air sehingga mudah ditambah air (dingin/panas), mudah larut dan siap disantap. Proses instan berjalan ideal apabila bubuk yang terkena 
media air menjadi basah dalam beberapa saat lalu tenggelam dan segera larut atau terdispersi secara merata dalam mediumnya ${ }^{7}$.

Pada umumnya gula digunakan untuk mengubah rasa dan keadaan makanan atau minuman. Gula sederhana seperti glukosa (yang diproduksi dari sukrosa dengan enzim atau hidrolisis asam) menyimpan energi yang akan digunakan oleh sel.

Sifat pengawet dari gula yaitu karena mengikat air dan efek osmosisnya gula menurunkan kadar air daging buah yang diawetkan. Pemberian gula dengan kadar tertentu akan menghambat pertumbuhan mikroorganisme pada buah yang diawetkan. Hal ini karena ada proses plasmolisis pada mikroba, yakni zat cair yang terkandung dalam tubuh mikroba akan tersebar keluar, disedot oleh daya osmosis dari gula ${ }^{7}$.

Minuman serbuk instan dari berbagai produk seperti jahe, kunyit, kopi, dan sebagainya, sudah banyak ditemukan. Dengan model dibuat serbuk instan manis, maka 1) mutu produk dapat terjaga, 2) tidak mudah terkotori, 3) tidak mudah terjangkiti penyakit, dan 4) produk tanpa pengawet. Dari sisi pemakaian, serbuk instan sangat mudah dibuat minuman hanya cukup menambahkan dengan air panas atau dingin, hal ini merupakan daya tarik masyarakat untuk mengkonsumsinya. Melalui proses pengolahan tertentu, minuman serbuk instan tidak akan mempengaruhi khasiat yang terkandung dalam bahan tersebut, sehingga baik untuk kesehatan badan ${ }^{8}$.

Minuman instan pala dibuat melalui dua tahapan proses yaitu proses pembuatan sari buah pala dengan bahan tambahan lainnya, diantaranya sirup glukosa, bahan pengisi dekstrin, $\mathrm{CMC}$, dan proses pengeringan ${ }^{1}$.

Pengolahan daging buah pala menjadi minuman serbuk instan selain berfungsi sebagai minuman penyegar dan juga sebagai minuman yang memiliki aspek fungsional bagi kesehatan dengan adanya antioksidan. Kapasitas antioksidan minuman sirup pala setara dengan $776 \mathrm{mg} / \mathrm{L}$ GAE(Gallic Acid Equivalent)persajian dan total fenolik sebesar $141 \mathrm{mg} / \mathrm{L}$ $\mathrm{GAE}^{9}$.Penelitian ini bertujuan antara lain, memanfaatkan daging buah pala untuk pembuatan minuman serbuk instan serta mendapatkan formulasi minuman serbuk instan daging buah pala.

\section{BAHAN DAN METODE}

\section{Bahan dan Alat}

Bahan-bahan yang digunakan dalam penelitian ini yaitu daging buah pala, asam sitrat, sukrosa, garam, kain saring, kemasan, serta bahan-bahan untuk analisis laboratorium.

Alat-alat yang akan digunakan terdiri dari timbangan, oven gelas ukur, thermometer, blender/ekstraktor, juicer, pengaduk hot plate, refraktometer, panci stainless steel, saringan, kukusan, kompor, dan peralatan untuk analisis laboratorium.

\section{Metode Penelitian}

Penelitian ini dilakukan dengan menggunakan Rancangan acak lengkap (RAL) dengan tiga kali ulangandengan perlakuan sari buah dan gula, dengan perbandingan :
A: Gula $90 \%$ : Sari Buah 10\%
B: Gula $80 \%$ : Sari Buah 20\% 
C : Gula 70\% : Sari Buah 30\%

D : Gula 60\% : Sari Buah $40 \%$

E: Gula 50\% : Sari Buah 50\%

\section{Prosedur Penelitian}

Buah pala yang sudah tua dipisahkan dagingnya dari biji dan fuli, dan diambil dagingnya.Buah yang telah dikupas kemudian dicuci, dimasukkan ke dalam rendaman air garam untuk mencegah terjadinya reaksi pencoklatan.Setelah itu daging buah paladiblansir selama 15 menit.Selanjutnya daging yang sudah diblansir dihancurkan menggunakan blender dengan penambahan air 1 : 3. Setelah didapatkan sari buah, disaring.Ditimbang gula sesuai perlakuan, diuapkan sampai menjadi larutan kental atau tua.Selanjutnya ditambahkan sari buah pala sesuai perlakuan yang sudah terlebih dahulu dinetralkan. Ke dalam larutan gula yang sudah kental sambil terus diaduk di atas api hingga membentuk serbuk kristal. Kristal gula diangkat, dimasukkan ke dalam oven pada suhu $55^{\circ} \mathrm{C}$ selama 4 jam. Tujuan dilakukan pengeringan adalah mengurangi kadar air, sehingga produk menjadi lebih awet serta mudah dalam pengangkutan karena memiliki volume dan berat yang lebih kecil.Setelah dikeringkan, ditambahkan asam sitrat $2 \% \mathrm{~b} / \mathrm{b}$, dilakukan penghancuran menggunakan blender untuk mendapatkan serbuk daging buah pala.Selanjutnya dilakukan proses pengayakan untuk mendapatkan serbuk yang seragam. Serbuk yang sudah jadi dikemas dan dilakukan analisis di laboratorium terhadap beberapa parameter pendukung.Untuk penyajian, produk serbuk minuman dilarutkan sebanyak 30 gram dalam $150 \mathrm{ml}$ air.Uji Organoleptik dilakukan terhadap 16 panelis.Diagram alir proses pembuatan serbuk instan daging buah pala dapat dilihat pada Gambar 1 .

\section{Pengamatan}

Pengamatan terhadap serbuk instan daging buah palameliputi beberapa parameter pada SNI 01-4320-2004 ${ }^{[10]}$, tentang Persyaratan Minuman Serbuk Tradisional, yaitu kadar gula; kadar air; kadar abu;uji mikrobiologi (Angka Lempeng Total dan Coliform); uji pH; Uji Organoleptik terhadap Rasa, Bau, dan Penampakan; dan Uji Kelarutan terhadap air.

\section{Analisis Data}

Data yang diperoleh diamati menggunakan analisis varians dan dilanjutkan dengan uji beda nyata terkecil apabila ada pengaruh perlakuan terhadap parameter yang diukur.

\section{HASIL DAN PEMBAHASAN}

\section{Hasil Pengamatan}

Hasil uji terhadap parameter fisik, kimia, dan mikrobiologiserbuk minuman daging buah pala dapat dilihat pada Tabel 1, sementara hasil uji organoleptik terhadap Rasa, Aroma, dan Penampakan dapat dilihat pada Tabel 2. 
Tabel 4. Hasil Uji Kandungan Serbuk Minuman Berbasis Daging Buah Pala

\begin{tabular}{cccccccc}
\hline Perlakuan & $\begin{array}{c}\text { Kadar } \\
\text { Sakarosa } \\
(\%)\end{array}$ & $\begin{array}{c}\text { Kadar } \\
\text { Air } \\
(\%)\end{array}$ & $\begin{array}{c}\text { Kadar } \\
\text { Abu } \\
(\%)\end{array}$ & pH & $\begin{array}{c}\text { Parameter } \\
\text { Lempeng } \\
\text { Total } \\
\text { (koloni/gr) }\end{array}$ & $\begin{array}{c}\text { Coliform } \\
\text { (APM/gr) }\end{array}$ & $\begin{array}{c}\text { Kelarutan } \\
(\%)\end{array}$ \\
\hline $\begin{array}{c}\text { Gula 90\%: } \\
\text { Sari Buah } \\
\quad 10 \%\end{array}$ & 99.33 & $0.266^{\mathrm{a}}$ & $0.05^{\mathrm{e}}$ & $3.02^{\mathrm{d}}$ & 310 & $<3$ & $99.784^{\mathrm{b}}$ \\
$\begin{array}{c}\text { Gula 80\%: } \\
\text { Sari Buah } \\
20 \%\end{array}$ & 98.55 & $0.276^{\mathrm{a}}$ & $0.23^{\mathrm{d}}$ & $3.02^{\mathrm{d}}$ & 10 & $<3$ & $99.844^{\mathrm{ab}}$ \\
$\begin{array}{c}\text { Gula 70\%: } \\
\text { Sari Buah } \\
30 \%\end{array}$ & 89.79 & $0.283^{\mathrm{a}}$ & $0.38^{\mathrm{c}}$ & $3.3^{\mathrm{c}}$ & 10 & $<3$ & $99.949^{\mathrm{a}}$ \\
$\begin{array}{c}\text { Gula 60\%: } \\
\text { Sari Buah } \\
40 \%\end{array}$ & 84.79 & $0.475^{\mathrm{a}}$ & $0.53^{\mathrm{b}}$ & $3.44^{\mathrm{b}}$ & 100 & $<3$ & $99.947^{\mathrm{ab}}$ \\
$\begin{array}{c}\text { Gula 50\%: } \\
\text { Sari Buah } \\
50 \%\end{array}$ & 75.04 & $0.5375^{\mathrm{a}}$ & $0.68^{\mathrm{a}}$ & $3.63^{\mathrm{a}}$ & 20 & $<3$ & $99.843^{\mathrm{ab}}$ \\
\hline
\end{tabular}

Huruf yang berbeda di belakang angka pada kolom yang sama menunjukkan perbedaan yang nyata $(P \leq 0,05)$

Tabel 5. Hasil Uji Organoleptik Serbuk Minuman Berbasis Daging Buah Pala

\begin{tabular}{|c|c|c|c|}
\hline \multirow{2}{*}{ Perlakuan } & \multicolumn{3}{|c|}{ Parameter } \\
\hline & Rasa & Aroma & Penampakan \\
\hline $\begin{array}{c}\text { Gula } 90 \% \text { : Sari Buah } \\
10 \%\end{array}$ & $3.000^{b}$ & $2.75^{b}$ & $2.94^{\mathrm{b}}$ \\
\hline $\begin{array}{c}\text { Gula } 80 \% \text { : Sari Buah } \\
20 \%\end{array}$ & $3.188^{a b}$ & $3.06^{\mathrm{ab}}$ & $3.25^{\mathrm{b}}$ \\
\hline $\begin{array}{c}\text { Gula } 70 \% \text { : Sari Buah } \\
30 \%\end{array}$ & $3.563^{a}$ & $3.25^{\mathrm{a}}$ & $3.5^{\mathrm{ab}}$ \\
\hline $\begin{array}{c}\text { Gula } 60 \% \text { : Sari Buah } \\
40 \%\end{array}$ & $3.563^{a}$ & $3.44^{a}$ & $3.88^{a}$ \\
\hline $\begin{array}{c}\text { Gula } 50 \% \text { : Sari Buah } \\
50 \%\end{array}$ & $3.375^{\mathrm{ab}}$ & $3.31^{a}$ & $3.94^{\mathrm{a}}$ \\
\hline
\end{tabular}

Huruf yang berbeda di belakang angka pada kolom yang sama menunjukkan perbedaan yang nyata $(P \leq 0,05)$

Skor penilaian organoleptik: 1=Sangat Tidak Suka; 2=Tidak Suka; 3=Agak Suka; 4= Suka; 5= Sangat Suka

\section{PEMBAHASAN}

\section{Kadar Sakarosa}

Hasil analisis terhadap kadar sakarosa serbuk instan daging buah pala berkisar antara $75.04-99.33 \%$ pada Gambar 2. Berdasarkan SNI 01-4320-2004 tentang Persyaratan Minuman Serbuk Tradisional, kadar gula yang dipersyaratkan maksimal $85 \%$. Peningkatan kadar sakarosaserbuk instan buah pala seiring dengan semakin besarnya proporsi sukrosa yang ditambahkan. Kadar sakarosa sari buah pala berasal dari gula sukrosa yang berperan sebagai agen osmosis. Semakin tinggi konsentrasi gula yang masuk kedalam bahan maka jumlah gula yang terukur akan semakin besar karena sukrosa sebagai gula nonreduksi, gula reduksi yang berasal dari buah, dan asam organik yang terbentuk terhitung sebagai total gula.Gula berfungsi sebagai penarik air dan molekul-molekul pektin. 



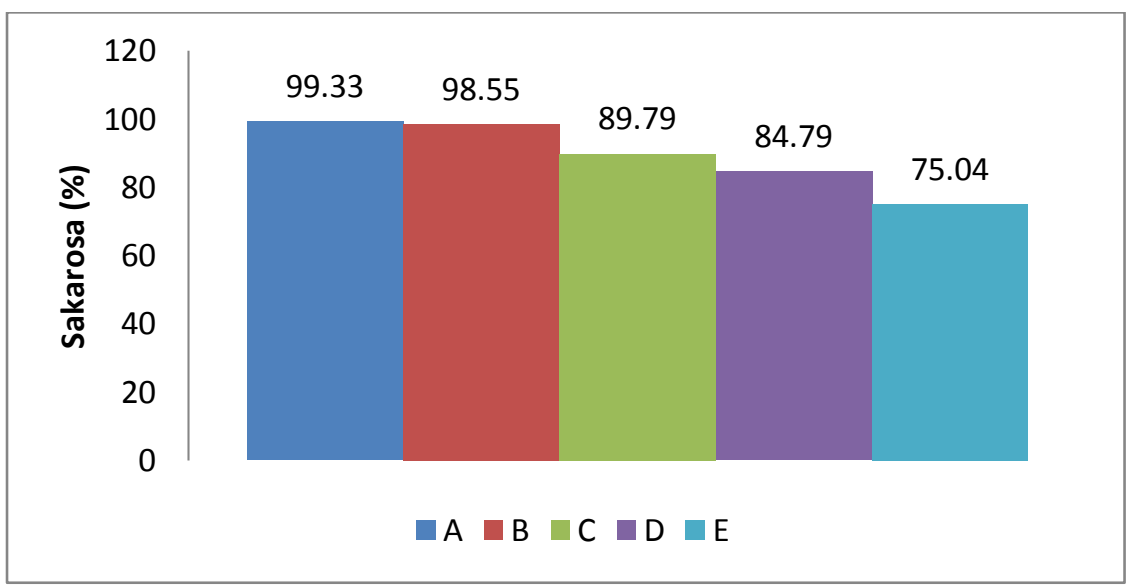

Gambar 2.Pengaruh Penambahan Gula : Sari Buah terhadap Kadar Sakarosa Minuman SerbukPala

\section{Kadar Air}

Berdasarkan SNI 01-4320-2004 tentang Persyaratan Minuman Serbuk Tradisional, kadar air yang dipersyaratkan maksimal $3 \%$. Kandungan air dalam bahan makanan ikut menentukan tingkat penerimaan, kesegaran, dan daya tahan produk pangan. Semakin tinggi kadar air, semakin mudah suatu produk pangan terserang mikroba selama proses penyimpanan. Gambar 3 menunjukkan hasil uji kadar air dari serbuk minuman berbasis daging buah pala yang berkisar antara $0.266-0.5375 \%$. Kadar air tertinggi terdapat pada perlakuan penambahan Gula 50\%: Sari Buah 50\%. Hasil tersebut memperlihatkan bahwa kadar air dari serbuk minuman berbasis daging buah pala cenderung meningkat dengan semakin banyaknya penambahan sari buahpala. Namun demikian, hasil analisis kadar air sesuai dengan kadar yang dipersyaratkan dalam SNI 01-4320-2004, yaitu 3\%. Rendahnya kadar air dapat disebabkan proses pengeringan yang telah berlangsung secara optimal dan produk langsung dikemas setelah melalui proses pengeringan. Penambahan sari buah akan memperlambat penguapan air sehingga pada waktu pemasakan yang lama maupun pada proses pengeringan diperoleh kadar air yang lebih tinggi.Hasil uji BNT menunjukkan bahwa keseluruhan perlakuan tidak menunjukkan perbedaan yang nyata.Kadar air dari serbuk minuman berbasis daging buah pala dipengaruhi oleh proses, suhu, waktu pengeringan, volume bahan, peralatan yang digunakan serta bahan baku itu sendiri. 


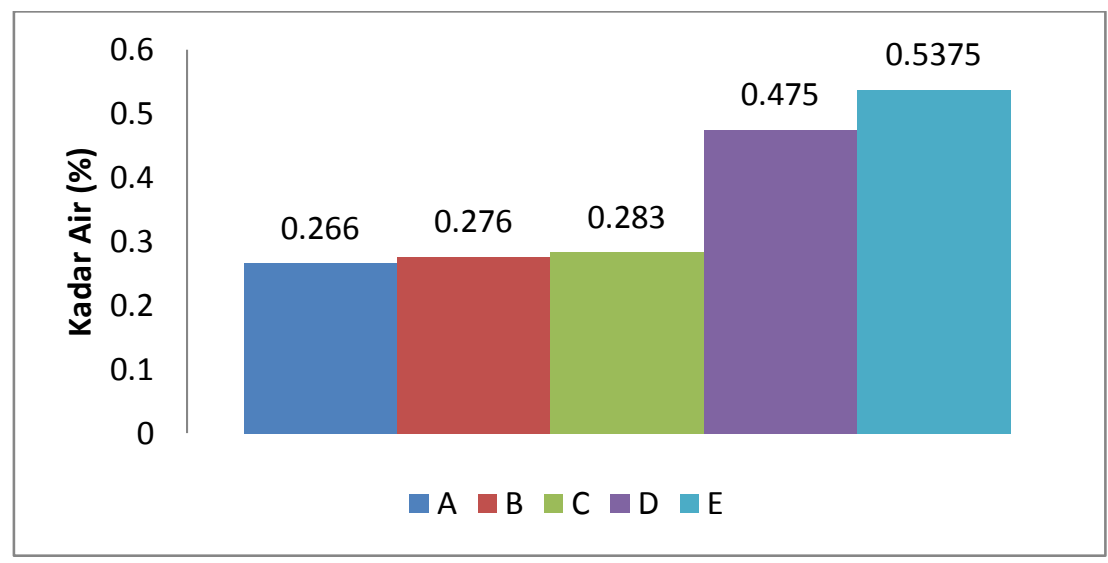

Gambar 3. Pengaruh Penambahan Gula : Sari Buah terhadap Kadar Air Minuman Serbuk Pala

\section{Kadar Abu}

Kadar abu merupakan salah satu parameter untuk menunjukkan kandungan bahan anorganik (mineral) yang ada di dalam bahan atau produk.Komponen bahan anorganik di dalam suatu bahan sangat bervariasi baik jenis maupun jumlahnya.Kandungan bahan anorganik yang terdapat di dalam suatu bahan diantaranya kalsium, kalium, fosfor, besi, magnesium, dan lain-lain. Hasil analisiskadar abu serbuk minuman instan daging buah pala pada Gambar 4berkisar antara $0.05-0.68 \%$. Hasil uji BNT menunjukkan bahwa keseluruhan perlakuan menunjukkan perbedaan yang nyata. Hal ini menunjukkan semakin tinggi nilai kadar abu, semakin banyak kandungan bahan anorganik di dalam produk tersebut.

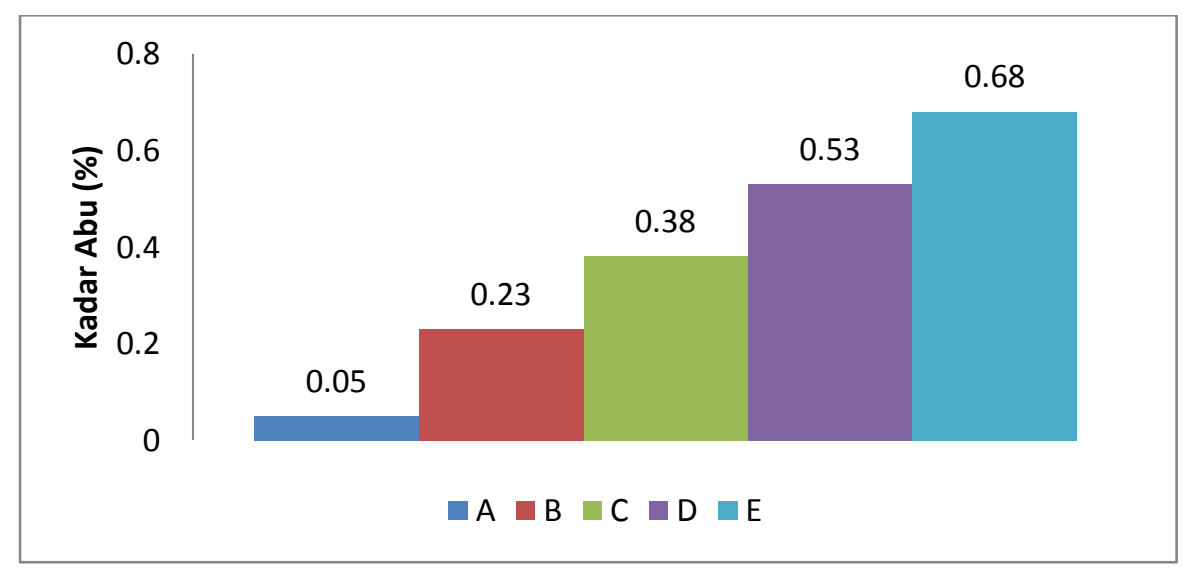

Gambar 4.Pengaruh Penambahan Gula : Sari Buah terhadap Kadar Abu Minuman Serbuk Pala

pH

Hasil analisis $\mathrm{pH}$ serbuk minuman instan daging buah pala pada Gambar 5berkisar antara 3.02-3.63.Kisaran $\mathrm{pH}$ tersebut merupakan $\mathrm{pH}$ asam, karenasemakin rendah nilai $\mathrm{pH}$ menunjukkan tingginya keasaman dari suatu produk. Terbentuknya $\mathrm{CO}_{2}$ pada saat reaksi serbuk dalam air yang sebagian akanlarut membentuk asam karbonat akan mengurangi ion $\mathrm{H}+$ dalam larutansehingga menyebabkan keasaman pada larutan dan berakibat nilai $\mathrm{pH}$ akanrendah ${ }^{11}$. Hasil uji 
BNT menunjukkan bahwa hampir keseluruhan perlakuan menunjukkan perbedaan yang nyata. Perlakuan penambahan gula $90 \%$ : sari buah $10 \%$ dan penambahan gula $80 \%$ : sari buah $20 \%$ tidak menunjukkan perbedaan yang nyata.

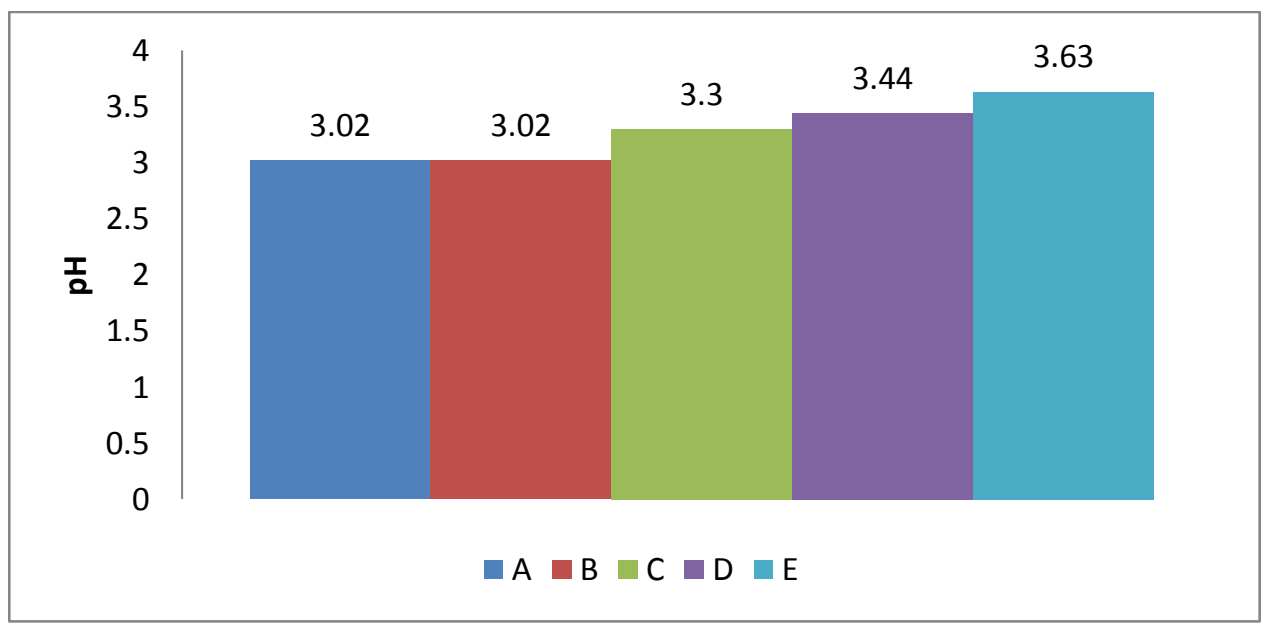

Gambar 5.Pengaruh Penambahan Gula : Sari Buah terhadap pH Minuman Serbuk Pala

\section{Uji Mikrobiologi (Angka Lempeng Total dan Coliform)}

Kontaminasi mikroba pada produk pangan dapat disebabkan oleh berbagai hal, yaitu alat, wadah, ruangan, udara yang terlibat dalam pengolahan, serta pekerja itu sendiri, atau kontaminasi silang dari produk jadi dari yang bercampur dengan bahan baku dan penanganan yang tidak baik setelah pengolahan $^{12}$. Oleh karena itu, uji mikrobiologi merupakan salah satu uji yang penting karena dapat digunakan sebagai indikator sanitasi atau indikator keamanan produk pangan. Hasil pengamatan terhadap Angka Lempeng Total pada serbuk minuman instan buah pala memiliki kisaran antara 10 310 koloni/g (Tabel 4). Kisaran nilai ini masih sesuai dengan persyaratan minuman serbuk tradisional pada SNI 01-4320-2004 yang menyaratkan maksimal jumlah angka lempeng total adalah 3000 koloni/g. Hasil tersebut menunjukkan bahwa minuman serbuk berbasis daging buah pala memenuhi
Standar Nasional Indonesia (SNI 01-43202004).

Pengujian bakteri coliform pada produk minuman serbuk instan daging buah pala dilakukan dengan menggunakan metode MPN (Most Probable Number) dengan menggunakan media BGLBB (Brilliant Green Lactose Bile) yang mengacu pada SNI 2897$1992^{13}$, tentang Cara Uji Cemaran Mikroba. Hasil positif uji coliform adalah terbentuk gelembung gas dan tabung durham menjadi keruh $^{[12]}$. Hasil pengamatan terhadap total coliform pada serbuk minuman instan buah pala adalah <3 APM/g untuk semua perlakuan (Tabel 4). Nilai ini sesuai dengan persyaratan minuman serbuk tradisional pada SNI 01-4320-2004 yang mensyaratkan bahwa total coliform minuman serbuk tradisional harus kurang dari $3(<3 \mathrm{APM} / \mathrm{g})$.

\section{Kelarutan}

Tingkat kelarutan adalah salah satu parameter yang penting untuk produkserbuk, 
termasuk minuman instan. Tingkat kelarutan padaminuman serbuk instan merupakan kemampuan untuk merehidrasi, sehingga seluruh komponen terlarut dapat larut dengan baik. Semakin besar nilai kelarutan berarti produk tersebut akan semakin cepat larut, mempermudah konsumen dalam penyajian produk, dan mengindikasikan mutu produk semakin baik. Kelarutan produk dipengaruhi oleh ukuran partikel dan kadar air produk. Semakin kecil ukuran partikel, maka luas permukaan semakin besar dan mudah larut. Pada produk berbentuk serbuk/tepung, semakin tinggi kadar air produk, semakin sulit produk dilarutkan dalam air karena produk cenderung membentuk butiran yang lebih besar tetapi tidak porous ${ }^{14}$. Semakin besar kelarutan, diharapkan semakin banyak komponen flavor yang terlarut.

Pengukuran tingkat kelarutan dilakukan dengan metode gravimetric, berdasarkan SNI 01-4239-1996 ${ }^{[15]}$. Hasil analisis pada Gambar 6 menunjukkan bahwa kelarutan serbuk minuman instan berbasis daging buah pala berkisar antara 99.78499.894\%.Perlakuan penambahan gula $70 \%$ :sari buah $30 \%$ memiliki kelarutan yang tertinggi. Hasil uji BNT menunjukkan bahwa sebagian besar perlakuan tidak menunjukkan perbedaan yang nyata. Perlakuan penambahan gula $70 \%$ :sari buah $30 \%$ berbeda nyata dengan perlakuan penambahan gula $90 \%$ :sari buah $10 \%$. Nilai kelarutan yang tinggi menunjukkan semakin baik mutu produk yang dihasilkan, karena proses penyajiannya menjadi lebih mudah.

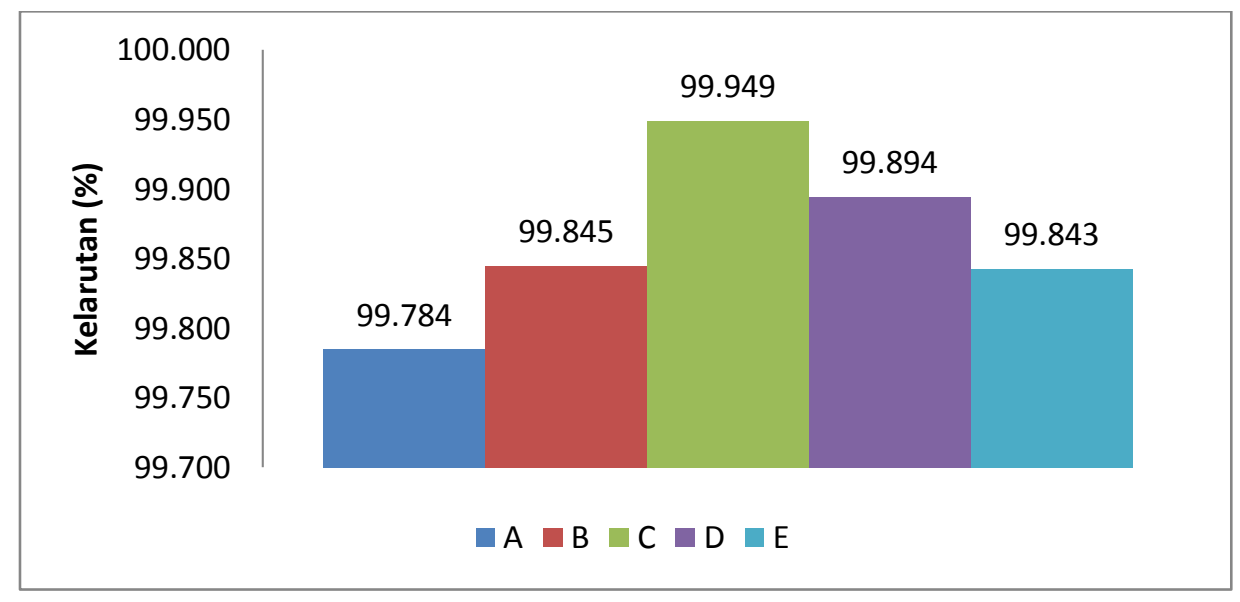

Gambar 6.Pengaruh Penambahan Gula : Sari Buah terhadap Kelarutan Minuman Serbuk Pala

\section{Organoleptik}

\section{Rasa}

Rasa merupakan salah satu parameter yang sangat menentukan penerimaan konsumen terhadap produk yang dihasilkan.Hasil uji organoleptik serbuk minuman berbasis daging buah pala terhadap rasa yang ditunjukkan pada Gambar 7 memperlihatkan bahwa rata-rata penilaian panelis terhadap parameter rasa berada pada kisaran 3-3.563.Uji BNT menunjukkan bahwa secara keseluruhan pengaruh perlakuan menunjukkan perbedaan yang nyata pada komponen rasa.Secara umum, hasil penilaian masih 
termasuk dalam kategori agak suka. Ratarata panelis lebih menyukai rasa serbuk minuman yang dibuat dengan variasi penambahan Gula 70\%:Sari Buah 30\% dan Gula 60\%:Sari Buah 40\%. Pada umumnya panelis mengemukakan bahwa rasa yang timbul dari produk tersebut terlalu asam dan belum menunjukkan rasa khas dari buah pala, khususnya padaperlakuan penambahan Gula 90\%:Sari Buah 10\%. Pada perlakuan penambahan sari buah yang lebih tinggi, rasa khas pala sudah mulai muncul, akan tetapi masih terlalu asam untuk dikonsumsi panelis. Hal ini disebabkan oleh adanya asam sitrat pada produk serta faktor sifat bahan baku yang pada awalnya sudah asam.

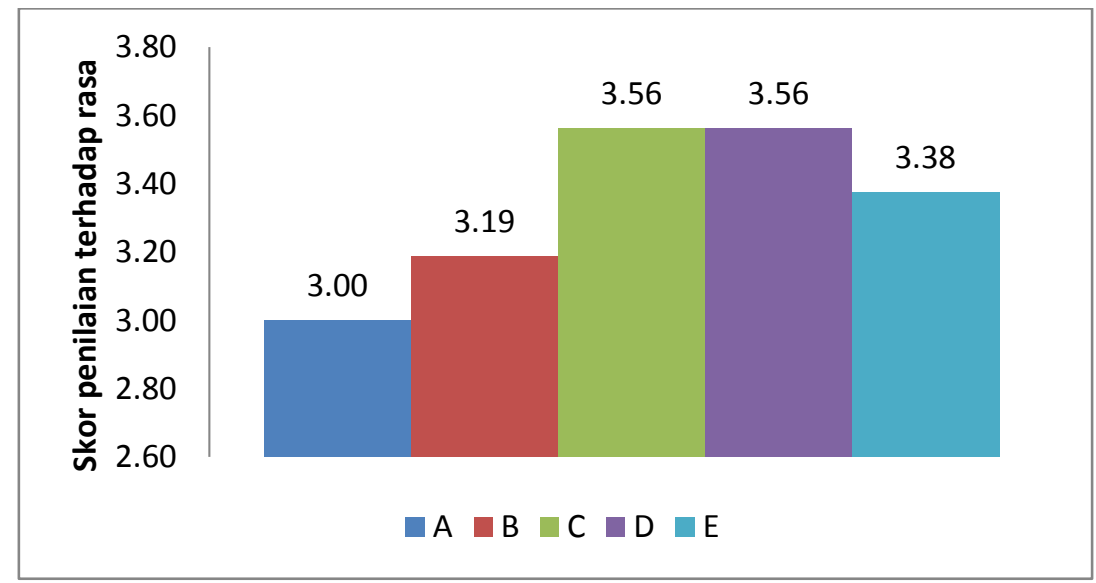

Gambar 7.Uji Organoleptik Pengaruh Penambahan Gula : Sari Buah terhadap Rasa Minuman Serbuk Pala

\section{Aroma}

Senyawa penting yang menentukan aroma pada serbuk instan berbasis daging buah pala adalah gula, adanya asam dan senyawa aromatis yang ada dalam buah pala.Hasil uji organoleptik skala hedonik terhadap aroma pada Gambar 8 menunjukkan bahwa rata-rata penilaian panelis terhadap aroma serbuk minuman berbasis daging buah pala berkisar antara
2.75-3.44.Uji BNT menunjukkan bahwa secara keseluruhan pengaruh perlakuan menunjukkan perbedaan yang nyata pada komponen aroma.Secara umum, hasil penilaian termasuk dalam kategori tidak suka sampai agak suka. Rata-rata panelis lebih menyukai rasa serbuk minuman yang dibuat dengan variasi penambahan Gula 60\% :Sari Buah 40\%. Pada umumnya panelis mengemukakan bahwa aroma yang timbul dari produk tersebut belum terlalu kuat. 


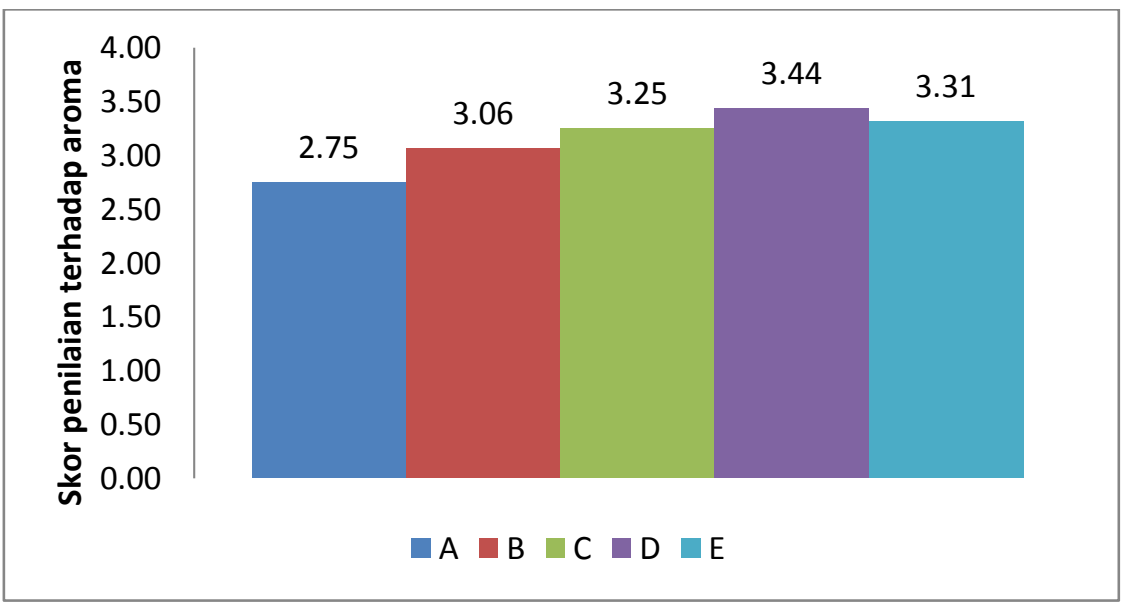

Gambar 8.Uji Organoleptik Pengaruh Penambahan Gula : Sari Buah terhadapAroma Minuman Serbuk Pala

\section{Penampakan}

Penampakan adalah kriteria penting karena dapat mempengaruhi penerimaan konsumen terhadap produk, karena panelis pertama kali akan menilai mutu produk pangan pada penampakan secara visual. Hasil uji organoleptik penampakan terhadap serbuk minuman berbasis daging buah pala pada Gambar 9menunjukkan bahwa ratarata penilaian panelis berkisar antara 2.943.94.Semakin tinggi konsentrasi penambahan sari buah pala pada pembuatan serbuk instan, tingkat kesukaan panelis terhadap penampakan semakin tinggi, yaitu 3.94.Uji BNT menunjukkan bahwa secara keseluruhan pengaruh perlakuan menunjukkan perbedaan yang nyata pada komponen penampakan.Secara umum, hasil penilaian termasuk dalam kategori agak suka sampai suka. Rata-rata panelis lebih menyukai penampakan serbuk minuman yang dibuat dengan variasi penambahan Gula 50\%:Sari Buah 50\%.

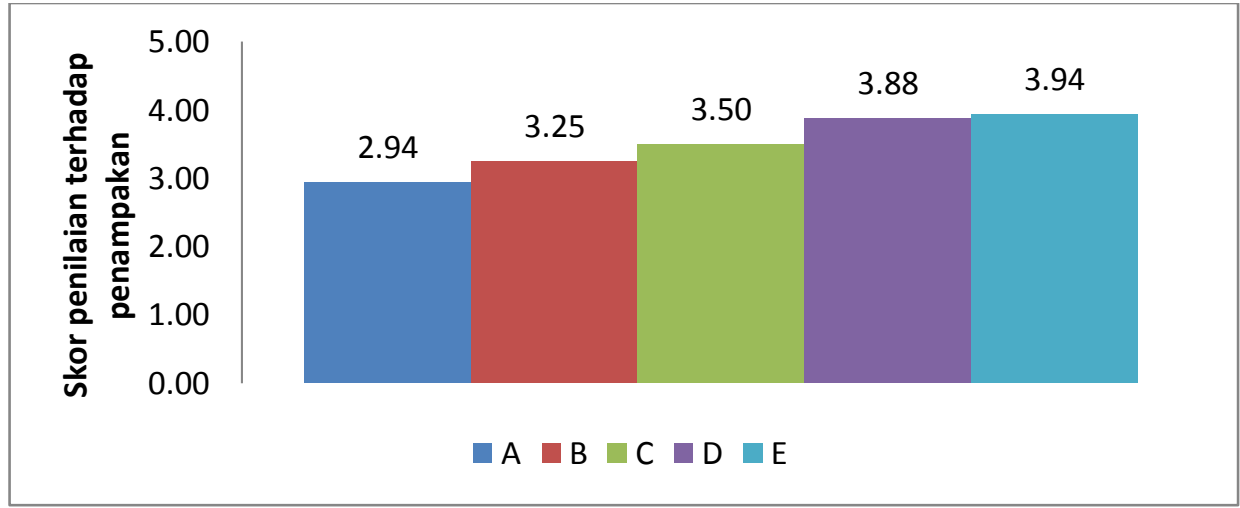

Gambar 9.Uji Organoleptik Pengaruh Penambahan Gula : Sari Buah terhadap Penampakan

\section{KESIMPULAN DAN SARAN}

\section{Kesimpulan}

Daging buah pala dapat dimanfaatkan untuk pembuatan minuman serbuk
instan.Perlakuan variasi perbandingan penambahan gula dan sari buah memiliki pengaruh yang nyata terhadap kadar $\mathrm{pH}$, kelarutan, dan parameter organoleptik yang meliputi rasa, aroma, dan penampakan, serta 
tidak memiliki pengaruh nyata terhadap kadar air. Serbuk minuman berbasis daging buah pala memenuhi syarat mutu SNI 014320-2004 untuk parameter kadar air dan parameter mikrobiologi yang meliputi angka lempeng total dan coliform. Perlakuan terbaik didapat pada variasi penambahan gula $60 \%$ : sari buah $40 \%$ yang menghasilkan serbuk minuman instan dengan kadar gula $84,79 \%$, kadar air 0,4\%, kadar abu 0,53\%, dan kelarutan $99,89 \%$, dengan uji organoleptik

\section{DAFTAR PUSTAKA}

1. Nurdjannah N. Teknologi Pengolahan Pala. Badan penelitian dan pengembangan pertanian: Balai besar penelitian dan pengembangan pascapanen pertanian; 2007.

2. Rismunandar. Budidaya dan Tataniaga pala. Jakarta: PT. Penebar Swadaya. Cetakan kedua; 1990

3. International Trade Centre. The Market for Sucrose Based Chemicals with Specific Reference to Citric Acid, Sorbitol and Sugar Esters. Geneva: UNCTAD/GATT; 1972.

4. Almatsier S. Prinsip Dasar IImu Gizi. Jakarta: PT Gramedia Pustaka Utama; 2001.

5. Winarno FG. Kimia Pangan dan Gizi. Jakarta: PT. Gramedia;2002.

6. Subagjo A. Manajemen Pengolahan Kue dan Roti. Yogyakarta: Graha IImu; 2007.

7. Hartomo AJ, Widiatmoko MJ. Emulsi dan Pangan Ber-Lesitin. Yogyakarta: Andi Offset;1992.

8. Rengga PWD, Handayani AP. Serbuk Instan Manis Daun Pepaya Sebagai terhadap rasa, aroma, dan penampakan cenderung lebih disukai panelis dengan skor penilaian agak suka.

\section{Saran}

Perlu dilakukan penelitian lanjutan terhadap perbandingan penambahan gula dan sari buah yang lebih disukai, dengan memperhatikan penambahan bahan tambahan yang optimal untuk memperbaiki sifat fisik serbuk instan daging buah pala baik sebelum maupun sesudah dilarutkan.

Upaya Mempelancar Air Susu Ibu. Jurnal Fakultas Teknik Kimia. Semarang: Unversitas Negeri Semarang; 2004.

9. Faridah ND, Sedarnawati $\mathrm{Y}$, Antin S, Ghesi W, Aryani. Pencirian Mutu Kimiawi dan Mikrobiologi Produk Bandrek Instan dan Sirup Buah Pala (Myristica fragrans). Jurnal IImu Pertanian Indonesia (JIP), April: 2013. Vol. 18(1) 43: 48.

10. Badan Standarisasi Nasional. SNI 014320-2004 tentang Persyaratan Minuman Serbuk Tradisional. Jakarta: Dewan Standarisasi Nasional;2004.

11. Kusnadhi FF. Formulasi Produk Minuman Instan Lingzhi-Jahe Effervescent. Skripsi. Fakultas Teknologi Pertanian. IPB. Bogor.2003.

12. Fardiaz S. Praktek Mikrobiologi Pangan. Lembaga Sumberdaya Informasi.IPB. Bogor. 1989

13. Badan Standarisasi Nasional. 1992. Cara Uji Cemaran Mikroba SNI 012897-1992. 
14. Koswara S. Jahe dan Hasil Olahannya.

Pustaka Sinar Harapan. Jakarta.1995.

15. Badan Standarisasi Nasional. 1996. SNI

01-4239-1996. 